\title{
Effects of different vegetable dust exposures'
}

\author{
F. VALIC and E. ŽUŠKIN \\ Andrija Śtampar School of Public Health, Zagreb University, Zagreb, Yugoslavia
}

\begin{abstract}
Valić, F., and Žuškin, E. (1972). Brit. J. industr. Med., 29, 293-297. Effects of different vegetable dust exposures. In order to establish the rank of biological activity of vegetable dusts, five groups of non-smoking female workers exposed to similar concentrations of hemp, flax, cotton, sisal, and jute airborne dust, respectively, were compared as to the prevalence of byssinosis, chronic respiratory symptoms, and one-second expiratory volume changes over the Monday shift. The groups were selected in such a way as to differ in the distribution of age and length of exposure to the respective dust as little as possible.

The prevalence of byssinosis in hemp and flax workers was approximately equal ( $44 \%$ and $43 \%$ respectively), in cotton workers it was considerably lower $(27 \%)$, while no byssinosis was caused by either sisal or jute dust. The highest prevalence of other chronic respiratory symptoms was recorded in hemp workers $(39 \%)$, followed by flax $(36 \%)$ and cotton workers $(27 \%)$, while in sisal $(13 \%)$ and jute workers $(13 \%)$ it was the lowest.

Significant mean FEV $_{1.0}$ reductions over the shift were recorded in all the groups of textile workers with the largest reductions in hemp workers $(19 \%)$ followed by flax $(11 \%)$, cotton $(8 \%)$, sisal $(7 \%)$, and jute workers $(5 \%)$. The application of orciprenaline before the shift diminished the mean acute $\mathrm{FEV}_{\mathbf{1 . 0}}$ falls over the work shift in all the groups studied.
\end{abstract}

These studies were undertaken first to establish the rank of biological potency of five different kinds of vegetable dust-hemp, flax, cotton, jute, and sisal and, secondly, to assess the degree of the preventive action of a bronchodilator against the effect of these dusts if applied before the beginning of the work shift. In order to avoid the complicating influence of smoking and the possible effect of sex on the vegetable dust effects, only female non-smoking workers were selected. In this study 102 female workers exposed to hemp dust, 139 to cotton dust, 91 to jute dust, 30 to flax dust, and 51 to sisal dust were examined. The hemp workers worked in two workrooms of a textile hemp processing plant while all the other groups worked each in one workroom of jute, flax, sisal, and cotton processing departments

'Partially presented at the International Conference of Occupational Health, Slanchev Bryag, September 20-24 1971. respectively. Identical studies were conducted in corresponding groups of non-smoking female workers exposed to no significant concentrations of any dust, selected in such a way as to match the respective exposed groups in the age and standing height distribution as much as possible (Table 1).

\section{Methods}

Airborne dust samples were collected by means of modified Hexhlet instruments (Wright, 1954) and the dust concentrations were determined separately for total dust and for respirable dust fractions, the latter being defined as the particle size fraction that passes the horizontal laminal plate elutriator constructed in conformity with the requirements of the British Medical Research Council for particle retention in the upper respiratory tract (Orenstein, 1960). Thirty-eight airborne dust samples were collected in the two hemp workrooms (with no significant difference in the concentrations of these two workrooms), 18 in the flax workroom, 28 in the cotton workroom, 19 in the jute workroom, and 26 in the sisal workroom. 
The one-second forced expiratory volume $\left(\mathrm{FEV}_{1.0}\right)$ was determined with Bernstein type spirometers before and after Monday work shifts.

In order to evaluate the preventive effect of a bronchodilator, orciprenaline (1-3,5-dihydroxyphenyl)-2-isopropylaminoethanol sulphate) was administered before the Monday shift to 44 hemp, 20 cotton, 16 jute, and 18 sisal female workers. The bronchodilator was applied as an aerosol by a pocket nebulizer delivering $750 \mu \mathrm{g}$ of active aerosol per puff. By applying two puffs and considering the aerosol penetration into the bronchial region to be $70-75 \%$ (Zidek, 1963), the examinee was exposed to a total dose of about $1 \cdot 1 \mathrm{mg}$ orciprenaline. ${ }^{1}$

Respiratory symptoms were recorded by using the British Medical Research Council questionnaire completed with some questions relating to characteristic symptoms of byssinosis (Schilling et al., 1964).

\section{Results}

Table 1 gives the mean airborne dust concentrations' the mean duration of exposure, the mean age and height of all the examined workers, their mean FEV $_{1.0}$ preshift values, and the mean changes of FEV $_{1 \cdot 0}$ over the Monday shift. The greatest acute

${ }^{1}$ Orciprenaline (Alupent) and nebulizers were supplied by Messrs. C. and H. Boehringer Sohn, Ingelheim, W. Germany.
FEV $_{1.0}$ fall over the shift was observed in hemp and flax workers and then in cotton workers. The acute $\mathrm{FEV}_{1.0}$ reductions were smaller in jute and sisal workers but were still highly significant $(P<0.01)$. No significant $\mathrm{FEV}_{1 \cdot 0}$ change over the shift was recorded in any of the control groups. The preshift mean $\mathrm{FEV}_{1.0}$ values of hemp, flax, and cotton workers were found to be significantly lower than in the corresponding control groups $(\mathrm{P}<0.01)$, whereas in jute and sisal workers this was not the case.

The prevalence of chronic respiratory symptoms, including byssinosis, in the five groups of textile workers is presented in Table 2. The rank order of respiratory effects is similar to that based on ventilatory function changes. The highest prevalence of byssinosis was observed in hemp (39\%) and flax $(40 \%)$ workers and then in cotton workers $(21 \%)$, while there was no byssinosis in either jute or sisal workers. The same rank order is obtained on the basis of the prevalence of other respiratory symptoms (chronic cough, chronic phlegm, chronic bronchitis, dyspnoea). A significantly higher prevalence of chronic respiratory symptoms was recorded in hemp, flax, and cotton workers than in the controls $(\mathbf{P}<$ 0.01 ). This was not the case in the jute or sisal workers.

TABLE 1

Mean Dust Concentrations, FeV $_{1.0}$ Preshift Values, AND FEV $_{1 \cdot 0}$ Changes OVER THE MONDAy SHIFT

\begin{tabular}{|c|c|c|c|c|c|c|c|c|c|}
\hline \multirow{3}{*}{ Group } & \multirow{3}{*}{$N$} & \multirow{2}{*}{\multicolumn{2}{|c|}{$\begin{array}{c}\text { Mean dust } \\
\text { concentrations } \\
\left(\mathrm{mg} / \mathrm{m}^{3}\right)\end{array}$}} & \multirow{3}{*}{$\begin{array}{c}\text { Mean } \\
\text { exposure } \\
(y r)\end{array}$} & \multirow{3}{*}{$\begin{array}{c}\text { Mean } \\
\text { age } \\
(y r)\end{array}$} & \multirow{3}{*}{$\begin{array}{c}\text { Mean } \\
\text { height } \\
(\mathrm{cm})\end{array}$} & \multicolumn{3}{|c|}{ Monday values } \\
\hline & & & & & & & \multirow{2}{*}{$\begin{array}{l}\text { Preshift } \\
\text { FEV } V_{1 \cdot 0} \\
\quad(m l)\end{array}$} & \multirow{2}{*}{$\begin{array}{c}F E V_{1 \cdot 0} \text { as } \% \\
\text { of control } \\
\text { group } \\
F E V_{1 \cdot 0}\end{array}$} & \multirow{2}{*}{$\begin{array}{l}\triangle F E V_{1 \cdot 0} \\
\quad(m l)\end{array}$} \\
\hline & & Total & $\begin{array}{c}\text { Respir- } \\
\text { able }\end{array}$ & & & & & & \\
\hline $\begin{array}{l}\text { Hemp } \quad . \\
\text { Control .. }\end{array}$ & $\begin{array}{r}102 \\
78\end{array}$ & $\begin{array}{r}16 \cdot 23 \\
-\end{array}$ & $\begin{array}{l}1 \cdot 76 \\
-\end{array}$ & $\begin{array}{l}10 \\
-\end{array}$ & $\begin{array}{r}34 \\
\mathrm{NS} \\
32\end{array}$ & $\begin{array}{l}158 \\
\text { NS } \\
158\end{array}$ & $\begin{array}{c}2754 \\
<0.01 \\
3247\end{array}$ & $84 \cdot 8$ & $\begin{array}{l}-425 \\
\quad<0.01 \\
+2\end{array}$ \\
\hline $\begin{array}{l}\text { Flax } \quad . \\
\text { Control } \ldots\end{array}$ & $\begin{array}{l}30 \\
60\end{array}$ & $\begin{array}{c}4 \cdot 36 \\
-\end{array}$ & * & $\begin{array}{l}10 \\
-\end{array}$ & $\begin{array}{r}32 \\
\text { NS } \\
35\end{array}$ & $\begin{array}{l}162 \\
\text { NS } \\
162\end{array}$ & $\begin{array}{rl}2 & 875 \\
& <0.01 \\
3 & 378\end{array}$ & $85 \cdot 1$ & $\begin{array}{c}-421 \\
<0.01 \\
0\end{array}$ \\
\hline $\begin{array}{l}\text { Cotton .. } \\
\text { Control .. }\end{array}$ & $\begin{array}{r}139 \\
90\end{array}$ & $\begin{array}{l}4 \cdot 10 \\
-\end{array}$ & $\begin{array}{c}0.55 \\
-\end{array}$ & - & $\begin{array}{r}32 \\
\text { NS } \\
34\end{array}$ & $\begin{array}{l}162 \\
\text { NS } \\
163\end{array}$ & $\begin{array}{c}3037 \\
<0.01 \\
3432\end{array}$ & $88 \cdot 5$ & $\begin{array}{c}-193 \\
<0.01 \\
+17\end{array}$ \\
\hline $\begin{array}{ll}\text { Jute } & \ldots \\
\text { Control } & .\end{array}$ & $\begin{array}{l}91 \\
60\end{array}$ & $\begin{array}{l}3 \cdot 22 \\
-\end{array}$ & $\begin{array}{c}0.73 \\
-\end{array}$ & $\begin{array}{r}3 \\
-\end{array}$ & $\begin{array}{r}23 \\
\text { NS } \\
24\end{array}$ & $\begin{array}{l}161 \\
\text { NS } \\
162\end{array}$ & $\begin{array}{l}3180 \\
\text { NS } \\
3193\end{array}$ & 99.6 & $\begin{array}{c}-121 \\
<0.01 \\
-10\end{array}$ \\
\hline $\begin{array}{ll}\text { Sisal } & \ldots \\
& \\
\text { Control .. }\end{array}$ & 51 & $\begin{array}{r}1.92 \\
-\end{array}$ & $\begin{array}{l}0.71 \\
-\end{array}$ & $\begin{array}{r}5 \\
-\end{array}$ & $\begin{array}{r}28 \\
\text { NS } \\
28\end{array}$ & $\begin{array}{l}160 \\
\text { NS } \\
160\end{array}$ & $\begin{array}{l}3034 \\
\text { NS } \\
3031\end{array}$ & $100 \cdot 1$ & $\begin{array}{c}-119 \\
<0.01 \\
+24\end{array}$ \\
\hline
\end{tabular}

* Respirable dust concentration was not measured in the flax mill.

$\mathrm{NS}=$ difference statistically not significant $(\mathrm{P}>0.05)$. 
TABLE 2

Prevalence of Chronic Respiratory Symptoms in Different Groups of Textile Workers

\begin{tabular}{|c|c|c|c|c|c|c|c|c|c|}
\hline Group & & $N$ & $\begin{array}{c}\text { Mean } \\
\text { exposure } \\
(y r)\end{array}$ & $\begin{array}{l}\text { Mean } \\
\text { age } \\
(y r)\end{array}$ & $\begin{array}{c}\text { Bys- } \\
\text { sinosis } \\
\%\end{array}$ & $\begin{array}{c}\text { Chronic } \\
\text { cough } \\
\%\end{array}$ & $\begin{array}{c}\text { Chronic } \\
\text { phlegm } \\
\%\end{array}$ & $\begin{array}{c}\text { Chronic } \\
\text { bronchitis } \\
\%\end{array}$ & $\begin{array}{c}\text { Dyspnoea } \\
\text { grades } 3 \text { and } 4 \\
\%\end{array}$ \\
\hline $\begin{array}{l}\text { Hemp } \\
\text { Flax } \\
\text { Cotton } \\
\text { Jute } \\
\text { Sisal }\end{array}$ & $\begin{array}{l}\ldots \\
\ldots \\
\ldots \\
\ldots \\
.\end{array}$ & $\begin{array}{r}102 \\
30 \\
139 \\
91 \\
51\end{array}$ & $\begin{array}{r}10 \\
10 \\
11 \\
3 \\
5\end{array}$ & $\begin{array}{l}34 \\
32 \\
32 \\
23 \\
28\end{array}$ & $\begin{array}{r}39 \\
40 \\
21 \\
0 \\
0\end{array}$ & $\begin{array}{l}53 \\
56 \\
35 \\
10 \\
18\end{array}$ & $\begin{array}{l}44 \\
49 \\
28 \\
13 \\
14\end{array}$ & $\begin{array}{l}40 \\
47 \\
28 \\
14 \\
10\end{array}$ & $\begin{array}{r}14 \\
13 \\
10 \\
1 \\
0\end{array}$ \\
\hline
\end{tabular}

A separate analysis of respiratory symptoms in byssinotic and non-byssinotic hemp, flax, and cotton workers (Table 3) shows a higher prevalence of all the respiratory symptoms in workers with byssinosis than in those without it. The acute mean $\mathrm{FEV}_{1.0}$ falls over the Monday shift were higher in byssinotics (Table 4) than in non-byssinotics (in flax workers the difference is not significant $-P>0.05$ ).

The examined groups of textile workers did not match in age or length of exposure to vegetable dust. The hemp, flax, and cotton workers were considerably older and had a longer duration of exposure. In order to establish a more or less reliable rank of biological activity of various kinds of vegetable dust, we attempted to find groups of non-smoking workers of the same sex in whom the difference in the mean exposure to hemp, flax, cotton, jute, and sisal dust and in the distribution of age and length of exposure would be as small as possible. We succeeded in find- ing only small groups of female workers meeting these requirements (18 hemp, 14 flax, 11 cotton, 15 jute, and 16 sisal workers; aged 22-29 yr; length of exposure 2-7 yr; mean dust concentration 1.92$\left.4.24 \mathrm{mg} / \mathrm{m}^{3}\right)$. As seen from the Figure, which presents the examination results obtained in these small groups, the prevalence of byssinosis in hemp and flax workers was approximately equal $(44 \%$ and $43 \%$ respectively), in cotton workers it was considerably lower $(27 \%)$, while jute and sisal dust caused no byssinotic changes at all. The prevalence of chronic respiratory symptoms was highest in hemp workers $(39 \%)$; it was lower in flax $(36 \%)$ and cotton workers $(27 \%)$, and was lowest in sisal and jute workers $(13 \%)$. The highest relative mean acute Monday reduction of FEV $_{1.0}$ was recorded in hemp workers $(19 \%)$ and then in flax $(11 \%)$, cotton $(8 \%)$, sisal $(7 \%)$, and jute $(5 \%)$ workers.

In order to assess the preventive effect of a

TABLE 3

Chronic Respiratory Symptoms in Hemp, Flax, and Cotton Workers WITH AND WITHOUT BYSSINOSIS

\begin{tabular}{|c|c|c|c|c|c|c|c|}
\hline Group & $N$ & $\begin{array}{c}\text { Mean } \\
\text { age } \\
(y r)\end{array}$ & $\begin{array}{c}\text { Mean } \\
\text { exposure } \\
(y r)\end{array}$ & $\begin{array}{c}\text { Chronic } \\
\text { cough } \\
\%\end{array}$ & $\begin{array}{c}\text { Chronic } \\
\text { phlegm } \\
\%\end{array}$ & $\begin{array}{c}\text { Chronic } \\
\text { bronchitis } \\
\%\end{array}$ & $\begin{array}{c}\text { Dyspnoea } \\
\text { grades } 3 \text { and } 4 \\
\%\end{array}$ \\
\hline $\begin{array}{l}\text { Hemp } \\
\text { With byssinosis } \\
\text { Without byssinosis }\end{array}$ & $\begin{array}{l}40 \\
62\end{array}$ & $\begin{array}{l}32 \\
35\end{array}$ & $\begin{array}{l}10 \\
10\end{array}$ & $P<\underset{37}{78} 0.01$ & $P<\underset{31}{65}$ & $P<\underset{30}{<6} 0.05$ & $\begin{array}{l}18 \\
\text { NS } \\
10\end{array}$ \\
\hline $\begin{array}{l}\text { Flax } \\
\text { With byssinosis } \\
\text { Without byssinosis }\end{array}$ & 18 & $\begin{array}{l}34 \\
31\end{array}$ & $\begin{array}{r}12 \\
9\end{array}$ & $\begin{array}{l}75 \\
\text { NS } \\
44\end{array}$ & $P<\underset{27}{78}$ & $P<\begin{array}{c}75 \\
<28\end{array}$ & $\begin{array}{l}17 \\
\text { NS } \\
11\end{array}$ \\
\hline $\begin{array}{l}\text { Cotton } \\
\text { With byssinosis }\end{array}$ & 110 & 31 & 11 & $\begin{array}{l}43 \\
\text { NS } \\
27\end{array}$ & $\begin{array}{l}35 \\
\text { NS } \\
15\end{array}$ & $\begin{array}{l}35 \\
\text { NS } \\
15\end{array}$ & $\begin{array}{c}15 \\
\text { NS } \\
7\end{array}$ \\
\hline
\end{tabular}

NS $=$ difference statistically not significant $(P>0.05)$. 
TABLE 4

FEV $_{\text {1.0 }}$ Values in Byssinotic and Non-byssinotic Hemp, Flax, and Cotton Workers

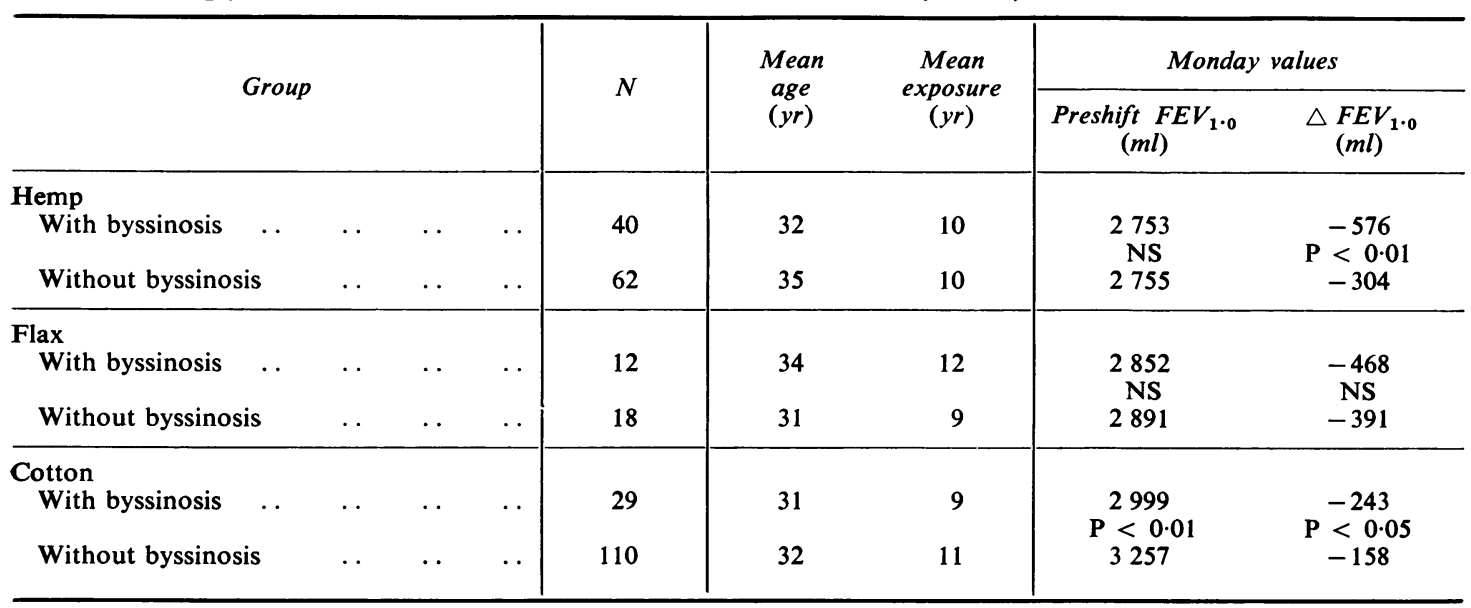

NS $=$ difference statistically not significant $(P>0.05)$.

bronchodilator on the bronchoconstriction caused by vegetable dust, orciprenaline was administered by inhalation before the Monday shift to 44 hemp, 20 cotton, 16 jute, and 18 sisal workers after their FEV $_{1.0}$ fall over the shift had been measured on the previous Monday. The workers were chosen from among those who showed the strongest respiratory

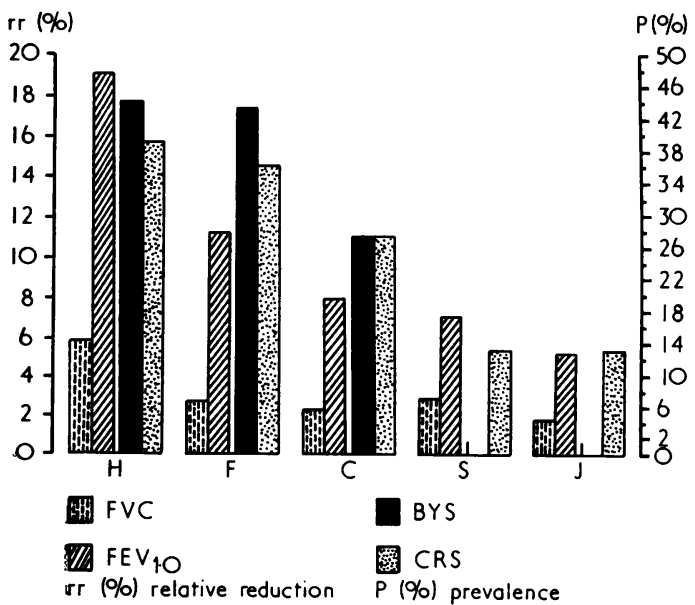

FIGURE Prevalence of byssinosis (BYS) and other chronic respiratory symptoms (CRS) $(\%)$ and acute FEV $_{1.0}$ and FVC reductions (\%) over work shift in selected groups of hemp, flax, cotton, jute, and sisal workers (age 22-29 yr; length of exposure 2-7 yr; dust concentrations $1 \cdot 92-4 \cdot 24 \mathrm{mg} / \mathrm{m}^{3}$ ). response to the respective vegetable dust (the strongest 'reactors'). There was a highly significant mean fall of $F E V_{1.0}$ over the shift in all the groups when no bronchodilator was applied $(\mathrm{P}<0.01)$ (Table 5). When orciprenaline was administered before the shift, an $\mathrm{FEV}_{1 \cdot 0}$ fall over the shift still existed but was significantly diminished.

\section{Discussion}

Although it was impossible to find sufficiently large groups of non-smoking textile workers of similar age and a similar length of exposure exposed to equal concentrations of airborne hemp, flax, cotton, jute, and sisal dust, we believe that the exposure levels of the workers studied were similar enough to allow a reasonably safe conclusion as to the relative potency of the five vegetable dusts. The rank order of the magnitude of the respective effects on the subjects exposed was (1) hemp, (2) flax, (3) cotton, (4) sisal, and (5) jute, irrespective of whether the prevalence of byssinosis or the prevalence of other non-specific respiratory symptoms, or the acute respiratory response $\left(\mathrm{FEV}_{1 \cdot 0}\right.$ fall over the shift) was taken as the basis for establishing the rank order. The workers studied were all in the 22-29 year age group and all were non-smokers of the same sex, so that the possible effect of age, sex difference, and difference in smoking habit was excluded. Whether, after a prolonged exposure to the respective vegetable dust, the rank order of the prevalence of chronic respiratory symptoms is subject to changes remains to be seen.

The preventive effect of the bronchodilator 
TABLE 5

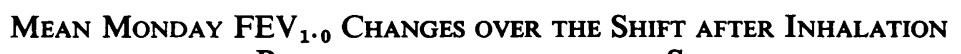
OF BRONCHODILATOR BEFORE THE SHIFT

\begin{tabular}{|c|c|c|c|c|c|c|c|c|c|}
\hline \multicolumn{4}{|c|}{ Group } & $N$ & $\begin{array}{l}\text { Mean change }(\mathrm{ml}) \\
\text { over shift without } \\
\text { bronchodilator }\end{array}$ & $\begin{array}{c}\mathbf{P} \\
\begin{array}{c}\text { before-after } \\
\text { shift }\end{array}\end{array}$ & $\begin{array}{c}\text { Mean change }(\mathrm{ml}) \\
\text { over shift after } \\
\text { bronchodilator }\end{array}$ & $\begin{array}{c}\mathbf{P} \\
\text { before-after } \\
\text { shift }\end{array}$ & $\underset{1-2}{P}$ \\
\hline \multicolumn{4}{|c|}{$\begin{array}{l}\text { Hemp } \\
\text { With byssinosis } \\
\text { Without byssinosis }\end{array}$} & $\begin{array}{l}20 \\
24\end{array}$ & $\begin{array}{l}-818 \\
-715\end{array}$ & $\begin{array}{l}<0.001 \\
<0.001\end{array}$ & $\begin{array}{l}-415 \\
-274\end{array}$ & $\begin{array}{l}<0.001 \\
<0.01\end{array}$ & $\begin{array}{l}<0.01 \\
<0.01\end{array}$ \\
\hline \multicolumn{4}{|c|}{$\begin{array}{l}\text { Cotton } \\
\text { With byssinosis } \\
\text { Without byssinosis }\end{array}$} & $\begin{array}{r}11 \\
9\end{array}$ & $\begin{array}{l}-401 \\
-320\end{array}$ & $\begin{array}{l}<0.01 \\
<0.01\end{array}$ & $\begin{array}{l}-239 \\
-157\end{array}$ & $\begin{array}{l}<0.01 \\
<0.05\end{array}$ & $\begin{array}{c}\text { NS } \\
<0.05\end{array}$ \\
\hline Jute & . & . & . & 16 & -245 & $<0.01$ & -98 & $<0.05$ & $<0.05$ \\
\hline Sisal & $\ldots$ & $\ldots$ & . & 18 & -276 & $<0.01$ & -69 & $<0.05$ & $<0.01$ \\
\hline
\end{tabular}

NS $=$ difference statistically not significant $(P>0.05)$.

application proved very pronounced. There is no doubt that the application of a bronchodilator before the shift significantly diminishes the acute fall of ventilatory lung capacity over the work shift caused by any of the five vegetable dusts. It remains to be examined whether the application of larger doses of orciprenaline enhances its preventive effect. The number of subjects interviewed regarding their subjective feeling during the shift after a preshift bronchodilator application was comparatively small but most of them claimed that they had felt better.

This investigation was supported in part by grant PL 480 Project 02-006-3 from the Bureau of Occupational Safety and Health, U.S. Public Health Service, Department of Health, Education and Welfare.

\section{References}

Orenstein, A. J. (Ed.) (1960). Proceedings of the Pneumoconiosis Conference, Johannesburg, 1959. Churchill, London.

Schilling, R. S. F., Vigliani, E. C., Lammers, B., Valic, F., and Gilson, J. C. (1964). A Report on a Conference on Byssinosis. Proc. XIVth int. Congr. occup. Hlth, Madrid, 1963, vol. 2, pp. 137-145. Excerpta Medica Foundation, Int. Congr. Ser. No. 62, Amsterdam.

Wright, B. M. (1954). A size-selecting sampler for airborne dust. Brit. J. industr. Med., 11, 284-288.

Zidek, R. (1963). Pneumometrische Untersuchungen und klinische Beobachtungen über den bronchospasmolytischen Effekt eines neuen antiasthmatischen SprühdosenInhalats. (Pneumometric studies and clinical observations on the bronchospasmolytic effect of a new antiasthmatic spray.) Med. Welt. (Stuttg.), 1421-1427.

Received for publication November 4, 1971. 